\title{
Insulin Stimulation of Glycogen Synthase Activity in Cultured Human Fibroblasts from Diabetic and Control Subjects
}

\author{
J. W. Craig ${ }^{1}$, L. S. Huang ${ }^{2}$, and J. Larner ${ }^{2}$ \\ Departments of ${ }^{1}$ Internal Medicine and ${ }^{2}$ Pharmacology, School of Medicine, University of Virginia, Charlottesville, Virginia, USA
}

\begin{abstract}
Summary. The influence of insulin on the enzyme glycogen synthase was studied in cultured skin fibroblasts from 5 non-diabetic subjects and 3 diabetic patients. Confluent fibroblast cultures were maintained in serum-free medium for 24 hours before exposure to graduated concentrations of insulin $(0.1$ to $2000 \mathrm{mU} / \mathrm{ml}$ ) for one hour. The independent form of glycogen synthase activity (determined in the absence of glucose-6-phosphate) was increased in some experiments by exposure of cells to $0.1 \mathrm{mU}$ of insulin $/ \mathrm{ml} ; 1.0 \mathrm{mU} / \mathrm{ml}$ produced a consistent increase; but at least $1000 \mathrm{mU} / \mathrm{ml}$ was required for maximum effect. In the non-diabetic subjects, the mean baseline total activity of glycogen synthase was $0.182 \mu \mathrm{mol} / \mathrm{mg}$ protein $/ \mathrm{h}$ with $16.8 \%$ in the independent form; with $1000 \mathrm{~m} \mathrm{U}$ of insulin $/ \mathrm{ml}$ the total activity was $0.167 \mu \mathrm{mol} / \mathrm{mg} / \mathrm{h}$ with $45.4 \%$ in the independent form. In the diabetic fibroblasts, the mean percentage of glycogen synthase in the independent form was lower than in the control cells at baseline and with all concentrations of insulin utilised; at baseline, total activity was $0.117 \mu \mathrm{mol} / \mathrm{mg}$ protein $/ \mathrm{h}$ with $11.7 \%$ in the independent form while with $1000 \mathrm{mU}$ of insulin $/ \mathrm{ml}$ the values were $0.146 \mu \mathrm{mol} / \mathrm{mg}$ protein $/ \mathrm{h}$ and $30.7 \%$ respectively. Demonstration of an effect of insulin on glycogen synthase in human fibroblasts provides another phenomenon for comparison in cells from control subjects and diabetic patients.
\end{abstract}

Key words: Glycogen synthase, cultured fibroblasts, insulin, diabetes mellitus.

A number of metabolic effects of insulin have been described in cultures of fibroblasts obtained from human skin. These effects include the enhancement of the uptake of glucose [1] and of alphaaminoisobutyrate [2], an increase in the incorporation of labelled carbon from glucose into carbon dioxide [3], and the restoration of glycogen levels in glycogen-depleted cells [4]. The incorporation of uridine into RNA and of leucine into protein are also stimulated by the exposure of cultured fibroblasts to insulin [1]. In cultures of these cells, a specific insulin receptor has been demonstrated [5].

Activation of the enzyme glycogen synthase by insulin has been demonstrated in several tissues. This enzyme exists in both active and inactive forms which are interconvertible by phosphorylation-dephosphorylation reactions. Dephosphorylated glycogen synthase is the active form and is recognised by the property of being independent of glucose-6-phosphate for activity. In the course of comparative studies of some biochemical characteristics of fibroblasts cultured from non-diabetic and diabetic human subjects, an effect of insulin on the activity of the enzyme glycogen synthase was demonstrated. This finding is the basis for the present report.

\section{Materials and Methods}

Fibroblast cultures were derived from punch biopsies of the skin of the upper lateral thigh of 5 normal adult volunteers and 3 diabetic patients; biopsies were obtained with the subjects in the fed state. The control subjects were Caucasian male students from 23 to 27 years of age with body weights from 106 to $109 \%$ of ideal. A 3 hour oral glucose tolerance test was performed on each control subject utilising a load of $75 \mathrm{~g}$ of carbohydrate; normal results were obtained in all by the criteria of Fajans and Conn [6]. None of the control subjects gave a family history of diabetes mellitus and none was taking any medication. Some of the clinical characteristics of the diabetic patients are shown in Table 1 . All 3 were Caucasian. Subjects 7 and 8 had a history of ketoacidosis, while Subject 6 required insulin to prevent diabetic symptoms. The blood glucose concentrations determined on the day of biopsy 
Table 1. Clinical characteristics of diabetic patients

\begin{tabular}{|c|c|c|c|c|c|c|}
\hline Subject & Age/Sex & $\begin{array}{l}\text { Body } \\
\text { weight } \\
\text { (\% ideal) }\end{array}$ & $\begin{array}{l}\text { Diabetes } \\
\text { duration } \\
\text { (years) }\end{array}$ & $\begin{array}{l}\text { Daily } \\
\text { insulin dose } \\
\text { (units) }\end{array}$ & $\begin{array}{l}\text { Other } \\
\text { medications }\end{array}$ & $\begin{array}{l}\text { Vascular } \\
\text { complications }\end{array}$ \\
\hline 6 & $28 / \mathrm{M}$ & 110 & 4 & $18^{\mathrm{a}}$ & None & 0 \\
\hline 7 & $25 / \mathrm{F}$ & 96 & 5 & 45 & None & 0 \\
\hline 8 & $36 / \mathrm{M}$ & 108 & 30 & 62 & $\begin{array}{l}\text { Hydrochloro- } \\
\text { thiazide } \\
50 \mathrm{mo}\end{array}$ & + \\
\hline
\end{tabular}

${ }^{a}$ Insulin therapy was begun 4 weeks before the skin biopsy was obtained

Table 2. Effect of insulin on independent activity of glycogen synthase in cultured skin fibroblasts

\begin{tabular}{|c|c|c|c|c|c|c|c|c|}
\hline \multirow[b]{2}{*}{ Subject } & \multirow[b]{2}{*}{ Experiments } & \multicolumn{7}{|c|}{ Concentrations of insulin $(\mathrm{mU} / \mathrm{ml})$} \\
\hline & & \multicolumn{7}{|c|}{ glycogen synthase, $\%$ independent activity ${ }^{b}$} \\
\hline & & \multicolumn{7}{|c|}{ Control subjects } \\
\hline 1 & 2 & 10 & 14 & & & 20 & 32 & \\
\hline 2 & 3 & 18 & 28 & & & 40 & 42 & \\
\hline 3 & 3 & 16 & 16 & 25 & 33 & 31 & 42 & 36 \\
\hline 4 & 5 & 21 & 21 & & & 42 & 53 & 42 \\
\hline 5 & 2 & 19 & 28 & & & & 58 & 64 \\
\hline Mean & & 16.8 & 21.4 & & & $33.2^{\mathrm{d}}$ & $45.4^{\mathrm{e}}$ & 47.3 \\
\hline \multirow[t]{2}{*}{ \pm SEM } & & \pm 1.9 & \pm 2.8 & & & \pm 5.0 & \pm 4.6 & \pm 8.5 \\
\hline & & \multicolumn{7}{|c|}{ Diabetic patients } \\
\hline 6 & 3 & 10 & 11 & 18 & 22 & 22 & 30 & 23 \\
\hline 7 & 3 & 13 & 13 & 15 & 20 & 23 & 26 & 28 \\
\hline 8 & 3 & 12 & 10 & & & 35 & 36 & \\
\hline Mean & & 11.7 & 11.3 & 16.5 & 21.0 & 26.7 & $30.7^{\mathrm{c}}$ & $26.5^{\mathrm{d}}$ \\
\hline \pm SEM & & \pm 0.9 & \pm 0.9 & \pm 1.5 & \pm 1.0 & \pm 4.2 & \pm 2.9 & \pm 2.5 \\
\hline
\end{tabular}

a Number of experiments; each insulin concentration for which a result is shown was studied in each experiment with that subject's cell line

b Glycogen synthase activity was measured in the presence of added glucose-6-phosphate $11 \mathrm{mmol} / \mathrm{l}$ (total activity) and in its absence (independent activity). \% independent activity $=\frac{\text { independent activity }}{\text { total activity }} \times 100$

Significantly different from 0 insulin: ${ }^{\mathrm{c}} \mathrm{p}<0.05,{ }^{\mathrm{d}} \mathrm{p}<0.01,{ }^{\mathrm{e}} \mathrm{p}<0.001$

Table 3. Effect of insulin on total activity of glycogen synthase in cultured skin fibroblasts

\begin{tabular}{llll}
\hline Subjects & $\begin{array}{l}\text { Insulin } \\
\text { concentration } \\
(\mathrm{mU} / \mathrm{ml})\end{array}$ & \multicolumn{2}{l}{$\begin{array}{l}\text { Glycogen synthase, total } \\
\text { activity }(\mu \mathrm{mol} / \mathrm{mg} \text { protein/h }\end{array}$} \\
\cline { 3 - 4 } & & Range & Mean $\pm \mathrm{SE}$ \\
\hline Control & 0 & $0.096-0.304$ & $0.182 \pm 0.063$ \\
& 1000 & $0.089-0.252$ & $0.167 \pm 0.047$ \\
Diabetic & 0 & $0.104-0.138$ & $0.117 \pm 0.011$ \\
& 1000 & $0.118-0.181$ & $0.146 \pm 0.018$ \\
\hline
\end{tabular}

ranged from 180 to $225 \mathrm{mg} / 100 \mathrm{ml}$ in the 3 patients. This clinical study was approved by the Human Investigation Committee of the University of Virginia Medical Center and informed consent was obtained in writing from each subject.

Experimental fibroblast cultures were studied between the fifth and eleventh passages or 10 to 22 mean population doublings beyond the primary culture. The cells were grown to confluence in $150 \mathrm{~mm}$ diameter plasticware tissue culture dishes (Falcon) con- taining $10 \mathrm{ml}$ of Dulbecco's modification of Eagle's medium (Grand Island Biological Company) with $4.5 \mathrm{~g} / 1$ of glucose and $10 \%$ fetal calf serum. No antibiotics were used. Incubation of the cultures was carried out at $37^{\circ} \mathrm{C}$ in a humidified atmosphere of $90 \%$ air and $10 \% \mathrm{CO}_{2}$. As the cells reached confluence and $24 \mathrm{~h}$ before the study, the medium was replaced with fresh Dulbecco's modification of Eagle's medium without fetal calf serum; before addition of the fresh medium, the cells were washed twice with serum-free medium to remove residual serum. Twentyfour $h$ later, graduated quantities of insulin were added to the medium in different dishes of the same cultured cell line to give the following final concentrations of insulin: $0,0.1,1.0,10,100,1000$, and $2000 \mathrm{mU} / \mathrm{ml}$. The dishes were then returned to the tissue culture incubator. One h later, they were removed, the cells harvested, and extracts prepared.

When the cells were harvested, the medium was aspirated from each dish and the monolayer of cells was washed three times with phosphate buffered saline, $(137 \mathrm{mmol} / \mathrm{l} \mathrm{NaCl}, 5.35 \mathrm{mmol} / \mathrm{l} \mathrm{KCl}$, $1.1 \mathrm{mmol} / 1 \mathrm{Na}_{2} \mathrm{HPO}_{4}, 1.0 \mathrm{mmol} / 1 \mathrm{KH}_{2} \mathrm{PO}_{4}$ ), pH 7.3), approximately $5 \mathrm{ml}$ for each wash. The cells in each dish were then scraped free, aspirated into a Pasteur pipette, transferred to a plastic test tube, and sedimented in a clinical centrifuge in the cold room. After the supernatants were decanted, each cell pellet was resus- 
pended in $0.5 \mathrm{ml}$ of $50 \mathrm{mmol} / 1$ glycylglycine, $2 \mathrm{mmol} / 1$ EDTA, $1 \mathrm{mmol} / \mathrm{l}$ DTT (dithiothreitol), $\mathrm{pH} 7.0$, buffer and homogenised in a Polytron homogeniser for $15 \mathrm{~s}$ at a setting of 6 . The homogenates were then centrifuged at $12,000 \times \mathrm{g}$ in a refrigerated centrifuge for $10 \mathrm{~min}$ and the supernatants were used for assay.

The activity of glycogen synthase in the extracts was measured by the method of Thomas et al. [7]. For assay of the glucose-6phosphate-independent or I form of activity, $30 \mu \mathrm{l}$ of tissue extract containing an average of $22 \mu \mathrm{g}$ of protein was added to $60 \mu \mathrm{l}$ of a test mixture. This test mixture contained $50 \mathrm{mmol} / 1$ Tris buffer (pH 7.8), $20 \mathrm{mmol} / 1 \mathrm{EDTA}, 25 \mathrm{mmol} / 1 \mathrm{KF}, 15 \mathrm{mmol} / 1 \mathrm{Na}_{2} \mathrm{SO}_{4}$, $10 \mathrm{mg} / \mathrm{ml}$ of glycogen, and $6.7 \mathrm{mmol} / 1$ UDP-(U- $\left.{ }^{14} \mathrm{C}\right)$ glucose (about $6 \times 10^{5} \mathrm{cpm} / \mu$ mole). Incubation was for $30 \mathrm{~min}$ at $30^{\circ} \mathrm{C}$. The independent activity of glycogen synthase was expressed as a percentage of the total synthase activity; the latter activity was measured under identical circumstances except for the presence of added glucose-6-phosphate $(11 \mathrm{mmol} / \mathrm{l})$ in the test mixture. The number of counts incorporated into glycogen in the assay was proportional to the time of incubation and to the quantity of the tissue extract which was employed.

The protein content of the tissue extracts was determined by the Lowry method [8] adapted for the AutoAnalyzer ${ }^{\circledR}$ (Technicon Instruments $\mathrm{Co}$.).

The insulin solutions which were used in these studies were prepared from either Novo monocomponent insulin (pork) or Lilly sodium insulin crystals (pork). The Novo insulin was zinc-free and contained less than $0.05 \%$ proinsulin-like material by radioimmunoassay, while the Lilly insulin contained $0.59 \%$ proinsulin and less than $0.003 \%$ glucagon. The Novo insulin was dissolved in $0.005 \mathrm{HCl}$; aliquots of a solution containing $10 \mathrm{U} / \mathrm{ml}$ were kept frozen and a new aliquot was freshly thawed for each experiment. A fresh aqueous solution of Lilly insulin was prepared from the crystals for each experiment in which it was used. Dilutions of the insulin solutions were made with Dulbecco's modification of Eagle's medium without fetal calf serum. No differences were observed in the results obtained with the two different insulin preparations. The insulin content of the insulin solutions and of the medium which was aspirated from the dishes of cultured cells at the end of the one $h$ incubation was determined by immunoassay. The method of Berson and Yalow [9] was modified by using solidphase antibody to separate bound and free insulin. Immunoassay of the solutions of insulin before addition to the culture medium yielded the predicted concentrations. In two experiments, the following percentages of the added insulin were present in the samples of medium at the end of the incubation: $71 \%$ in the medium to which $0.1 \mathrm{mU} / \mathrm{ml}$ has been added; $59 \%$ of $1.0 \mathrm{mU} / \mathrm{ml} ; 100 \%$ of $10.0 \mathrm{mU} / \mathrm{ml} ; 104 \%$ of $1000 \mathrm{mU} / \mathrm{ml}$; and $96 \%$ of $2000 \mathrm{mU} / \mathrm{ml}$.

Statistical analysis was performed using Student's $t$-test. Unpaired analysis was used in comparing results from diabetic and control subjects, and the paired test was used to compare the effects of different concentrations of insulin. Differences were considered significant when $\mathrm{p}<0.05$.

\section{Results}

As shown in Table 2, the independent form of glycogen synthase activity was increased by exposure of the cells to insulin. In several experiments, as little as $0.1 \mathrm{mU}$ of insulin $/ \mathrm{ml}$ of medium was associated with an increase in the independent form of activity, but the mean change with this concentration of insulin was not statistically significant. A concentration of $1.0 \mathrm{mU}$ of insulin $/ \mathrm{ml}$ of medium consistently pro- duced an increase in the independent form of glycogen synthase activity. However, at least $1000 \mathrm{mU} / \mathrm{ml}$ was required for a maximum effect. The total activity of the enzyme was not altered by the short-term addition of insulin (Table 3 ).

The mean percentage of glycogen synthase activity in the independent form was greater in fibroblasts cultured from the 5 control subjects than in those from the 3 diabetic patients both without insulin and in its presence. However, the differences were significant only at insulin concentrations of $0(p<0.01)$ and $0.1 \mathrm{mU} / \mathrm{ml}(\mathrm{p}<0.001)$. The average increase produced by insulin in the independent form of glycogen synthase activity tended to be greater in the control cells than in the diabetic cells at all insulin concentrations studied.

Repeat experiments on the same cell line yielded similar but not identical results in most instances. As an example, the following mean values and ranges for the percentage of glycogen synthase activity in the independent form were derived from five experiments with cultured fibroblasts from non-diabetic subject 4: Basal level without insulin: 21 (18-26), with $0.1 \mathrm{U} / \mathrm{ml}$ insulin: $21(16-26), 100 \mathrm{U} / \mathrm{ml}: 42$ (33-48), $1000 \mathrm{U} / \mathrm{ml}: 53$ (46-61), $2000 \mathrm{U} / \mathrm{ml}: 42$ $(31-48)$. The reproducibility was similar with diabetic and with control cells.

That the increased independent activity in the presence of insulin was not due to an accumulation of glucose-6-phosphate was demonstrated by precipitating the enzyme with ammonium sulphate. When the protein was redissolved, preparations from insulin-treated cells retained their greater independent activity.

\section{Discussion}

Several comparisons of the characteristics of cultured skin fibroblasts from non-diabetic subjects and from diabetic patients have been published. Decreased plating efficiency [10] and a reduced number of cell doublings prior to cessation of growth [11] have been found in diabetic cells. A reduced growth rate has been observed during the exponential phase in cells from patients with insulin-dependent diabetes and a diminished final cell density has been noted in cells from both insulin-dependent and insulin-independent patients [12]. No difference was observed by one group of investigators in the baseline or insulinstimulated rate of conversion of glucose $-{ }^{14} \mathrm{C}$ to ${ }^{14} \mathrm{CO}_{2}$ in cells from normal and diabetic subjects [3], but two studies of small numbers of patients have been reported in abstract form to show less stimulation of glucose $-{ }^{14} \mathrm{C}$ to ${ }^{14} \mathrm{CO}_{2}$ by insulin in cells from diabetic 
patients than in cells from aborted fetuses [13] or normal human skin [14]. The incorporation of acetate into cholesterol esters was greater in diabetic fibroblasts than in those from non-diabetic subjects [15]. Abnormal rates of protein and collagen synthesis and different effects of cortisol on these processes have been described in fibroblasts cultured from insulin-dependent and insulin-independent diabetic patients [12]. Cultured diabetic fibroblasts were found to have increased proportions of heparan sulphate in the media relative to the other sulphated glycosaminoglycans [16]. Differences in lysosomal glycohydrolase activities in cultured skin fibroblasts from diabetic and control subjects have also been reported [17]. In one study, the specific binding of insulin to fibroblasts cultured from diabetic patients did not appear to differ from normal, but the clinical characteristics of the diabetic patients were not described [18].

The enzyme glycogen synthase was selected for investigation in the present study because its activation appears to be a universal marker of insulin action, unlike some other effects of the hormone [19] such as stimulation of glucose transport. The occurrence of glycogen synthase activity in fibroblasts cultured from the skin of normal subjects has been reported by DiMauro, Rowland, and Mellman [20]. Their measurements were made in the presence of added glucose-6-phosphate and, therefore, represented total synthase activity. However, this is the first report of activation of the enzyme by insulin in cultured human skin fibroblasts.

Like some of the metabolic effects of insulin which have been described in cultured fibroblasts [1, $3,4]$, a relatively high concentration of insulin is required to produce a maximum effect on the enzyme glycogen synthase. Alteration of the cell surface by trypsinisation [21] was not felt to be a factor in these studies since the cells had been grown to confluence after the previous trypsinisation and were exposed to insulin while in an undisturbed monolayer. It has also been suggested that the fibroblast may not be a primary target tissue for insulin and that its receptor is intended for some other closely related insulin-like polypeptide [2].

Our finding of a lower basal level of the independent form of glycogen synthase activity in diabetic cells may be a characteristic of later generations of cells and reflect the accelerated rate of cell death and replenishment which has been postulated to occur in diabetic tissues [11]. No data are available regarding the effect of the donor's age on glycogen synthase activity in cultured fibroblasts. In our studies, no consistent difference was noted in the glycogen synthase activity of cells from the fifth to the eleventh passages. Studies of fibroblasts cultured from additional diabetic patients will be required to confirm the difference observed between normal and diabetic cells in these preliminary studies. Two of the diabetic patients studied had a history of ketoacidosis and the third was a young man who required insulin to prevent symptoms. Since insulin-independent patients have evidence of insulin resistance [22], their peripheral tissues are a more likely site for a biochemical aberration than the cells of the insulindependent diabetic patients reported in the present paper. Studies of such patients are in progress.

This study adds another action of insulin to those previously described in fibroblasts cultured from human skin. In the small number of diabetic patients studied, an abnormality of glycogen synthase activity was observed.

Acknowledgements. The indispensible contribution of Dr. Alfred G. Gilman and Ms. Hannah Anderson in the culturing of the fibroblasts is acknowledged. We wish to thank Mr. Howard Froehlich for technical assistance and Dr. Elsa P. Paulsen for the radioimmunoassay of insulin.

This work was supported by U.S. Public Health Service grants AM 15334, AM 17042 (the University of Virginia Diabetes Research Center), and RR 847 (the Clinical Research Center at the University of Virginia Medical Center). Dr. Larner is an Established Investigator of the American Diabetes Association, and Dr. Huang is the Recipient of a Research Career Development Award from the National Institute of Arthritis, Metabolism, and Digestive Diseases (1 KO4 AM 00212).

A generous gift of insulin was received from Eli Lilly and Company.

\section{References}

1. Fujimoto, W. Y., Williams, R. H.: Insulin action on the cultured human fibroblast. Glucose uptake, protein synthesis. RNA synthesis. Diabetes 23, 443-448 (1974)

2. Hollenberg, M.D., Cuatrecasas, P.: Insulin and epidermal growth factor. Human fibroblast receptors related to deoxyribonucleic acid synthesis and amino acid uptake. J. Biol. Chem. 250, 3845-3853 (1975)

3. Goldstein, S., Littlefield, J. W.: Effect of insulin on the conversion of glucose-C-14 to C-14- $0_{2}$ by normal and diabetic fibroblasts in culture. Diabetes 18, 545-549 (1969)

4. DiMauro, S., Mellman, W. J.: Glycogen metabolism of human diploid fibroblast cells in culture. II. Factors influencing glycogen concentration. Pediatr. Res. 7, 745-750 (1973)

5. Rechler, M. M., Podskalny, J. M.: Insulin receptors in cultured human fibroblasts. Diabetes 25, 250-255 (1976)

6. Fajans, S.S., Conn, J.S.: The early recognition of diabetes mellitus. Ann. N. Y. Acad. Sci. 82, 208-218 (1959)

7. Thomas, J.A., Schlender, K. K., Larner, J.: A rapid filter paper assay for UDP glucose-glycogen glycosyltransferase, including an improved biosynthesis of UDP-14C-glucose. Anal. Biochem. 25, 486-499 (1968)

8. Lowry, O. H., Rosebrough, N. J., Farr, A. L., Randall, R. J.: Protein measurement with the Folin phenol reagent. J. Biol. Chem. 193, 265-275 (1951)

9. Yalow, R. S., Berson, S. A.: Assay of plasma insulin in human 
subjects by immunological methods. Nature 21, 1648-1649 (1959)

10. Goldstein, S., Littlefield, J. W., Soeldner, J. S.: Diabetes mellitus and aging: diminished plating efficiency of cultured human fibroblasts. Proc. Natl. Acad. Sci. USA 64, 155-160 (1969)

11. Vracko, R., Benditt, E. P.: Manifestations of diabetes mellitustheir possible relationships to an underlying cell defect. Am. J. Pathol. 75, 204-221 (1974)

12. Rowe, D. W., Starman, B. J., Fujimoto, W. Y., Williams, R. H.: Abnormalities in proliferation and protein synthesis in skin fibroblast cultures from patients with diabetes mellitus. Diabetes 26, 284-290 (1977)

13. Fujimoto, W. Y., Williams, R. H.: Glucose oxidation in cultured fibroblasts (abstract). Diabetes 21, 360 (1972)

14. Wolf, S. A., Gertner, M., Hirschhorn, K., Knittle, J. L.: Effect of insulin on $\mathrm{C}-14-\mathrm{O}_{2}$ production by cultured fibroblasts from normal and diabetic subjects (abstract). Diabetes 20, 383 (1971)

15. Cooper, J. T., Goldstein, S.: De novo synthesis of lipids and incorporation of oleic acid into cultured human fibroblasts from diabetics and normal controls. Atherosclerosis 20, 41-50 (1974)

16. Silbert, C. K., Kleinman, H. K.: Studies of cultured human fibroblasts in diabetes mellitus: changes in heparan sulfate. Diabetes 28, 61-64 (1979)

17. Nakagawa, S., Goldstein, B. M., Kumin, S., Nitowsky, H. M.: Lysosomal glycohydrolase activities in fibroblast cultures from patients with diabetes mellitus (abstract). Fed. Proc. 36, 792 (1977)
18. Gorman, R. E., Aghajanian, J. D., Swift, M.: Insulin binding to cultured human fibroblasts at physiologic concentrations (abstract). Clin. Res. 23, 12 (1975)

19. Lamer, J.: Four questions times two: a dialogue on the mechanism of insulin action dedicated to Earl W. Sutherland. Metabolism 24, 249-256 (1975)

20. DiMauro, S., Rowland, L. P., Mellman, W. J.: Glycogen metabolism of human diploid fibroblast cells in culture. I. Studies of cells from patients with glycogenosis Types II, III, and V. Pediatr. Res. 7, 739-744 (1973)

21. Kono, T., Barham, F. W.: The relationship between the insulin-binding capacity of fat cells and the cellular response to insulin. Studies with intact and trypsin-treated fat cells. J. Biol. Chem. 246, 6210-6216 (1971)

22. Ginsberg, H., Kimmerling, G., Olefsky, J. M., Reaven, G. M.: Demonstration of insulin resistance in untreated adult onset diabetic subjects with fasting hyperglycemia. J. Clin. Invest. $\mathbf{5 5}, 454-461(1975)$

Received: January 25, 1979 ,

and in revised form: August 6, 1979

James W. Craig, M. D.

Box 458

School of Medicine

University of Virginia

Charlottesville, VA 22908

USA 